\title{
Clinical Reasoning: 63-Year-old woman with thoracic cavernous malformation and delayed worsening myelopathy
}

Elisa Colombo, MD, Giuseppe Lanzino, MD, Robert D. Brown, Jr., MD, and Benjamin D. Elder, MD, PhD

Neurology ${ }^{\circledR}$ 2019;93:1075-1078. doi:10.1212/WNL.0000000000008635
Correspondence

Dr. Lanzino

Lanzino.giuseppe@

mayo.edu

\section{Section 1}

A 63-year-old woman presented with marked, progressive worsening of lower extremity spasticity and decreased upper extremity strength. In 1980, she developed lower extremity paresthesias and was found to have an intramedullary hemorrhagic lesion at T3. She underwent a laminectomy at $\mathrm{T} 1-\mathrm{T} 4$ and partial resection of a cavernous malformation (CM). Apart from a single, transient worsening of lower extremity sensory symptoms in 1985 (due to CM rebleeding), she did not experience any further exacerbations. At the time of evaluation at our institution, she had noticed worsening leg spasms and difficulty with her gait, as well as decreased muscle bulk, most pronounced in the quadriceps. These symptoms had developed over several months. She also reported worsening strength and endurance in the upper extremities, difficulties with fine motor movements, and dysphagia. She did not report new sensory deficits in her upper extremities or bowel or bladder dysfunction. On examination, she had a spastic gait but was able to walk with a cane. She had mild weakness, Medical Research Council grade 4, in the lower extremities and normal strength in the upper extremities, except for mild weakness, about 4/5 strength, in finger and wrist extension, in the interossei, and proximally. She had 3+ patellar and ankle reflexes, normal reflexes in the upper extremities, and extensor plantar responses bilaterally. Jaw jerk was not assessed. She had marked spasticity in the lower extremities with normal tone in the upper extremities. She had a T5 sensory level to temperature.

\section{Questions for consideration:}

1. Based on history and examination, what could explain worsening symptoms?

2. Which details of the patient's history are most relevant?

\section{GO TO SECTION 2}




\section{Section 2}

The patient's prior spine imaging showed postoperative changes, stable appearance of the thoracic CM, and spinal cord tethering at the laminectomy site. Brain MRIs done before the current exacerbation revealed stable findings, with multiple supratentorial and infratentorial CMs. An MRI of the thoracic spine was repeated and did not show any new changes. Cervical spine MRI demonstrated retrolisthesis of C5 on C6 with moderate central canal stenosis. Lack of changes in CM appearance indicated that the new progressive symptoms were not related to it (explanation of Question 2 from Section 1).

\section{Questions for consideration:}

1. What is the most important finding on the recent MRIs?

2. Which additional diagnostic testing can further clarify the underlying etiology for the worsening symptoms?

GO TO SECTION 3 


\section{Section 3}

The differential diagnoses to explain the patient's subacute neurologic deterioration include tethering of the spinal cord at the prior resection site, a microbleed from the known CM, a primary neurologic condition, or cervical spondylotic myelopathy from stenosis at C5-C6 superimposed on an already diseased spinal cord. A comprehensive EMG study of the upper and lower extremities was normal, with no evidence of a generalized neuropathic or myopathic process. Extensive blood tests were normal, including acetylcholine receptor antibodies. A detailed gastroenterology evaluation for dysphagia revealed a disorder of esophageal motility. The degree of spinal stenosis at
C5-C6 was moderate on static MRI and without significant cord compression or $\mathrm{T} 2$ signal changes in the spinal cord. A slight increase of the C5-C6 retrolisthesis in extension was noted on dynamic flexion-extension X-rays. Therefore, a flexion-extension MRI of the cervical spine was pursued, which indeed revealed significant worsening of the C5-C6 stenosis in extension (figure). Bone density assessment was consistent with osteoporosis.

\section{Questions for consideration:}

1. Would you recommend surgery for this patient?

2. If the above answer is yes, would dysphagia and bone frailty influence the surgical approach?

Figure Comparison among cervical spine MRI examinations

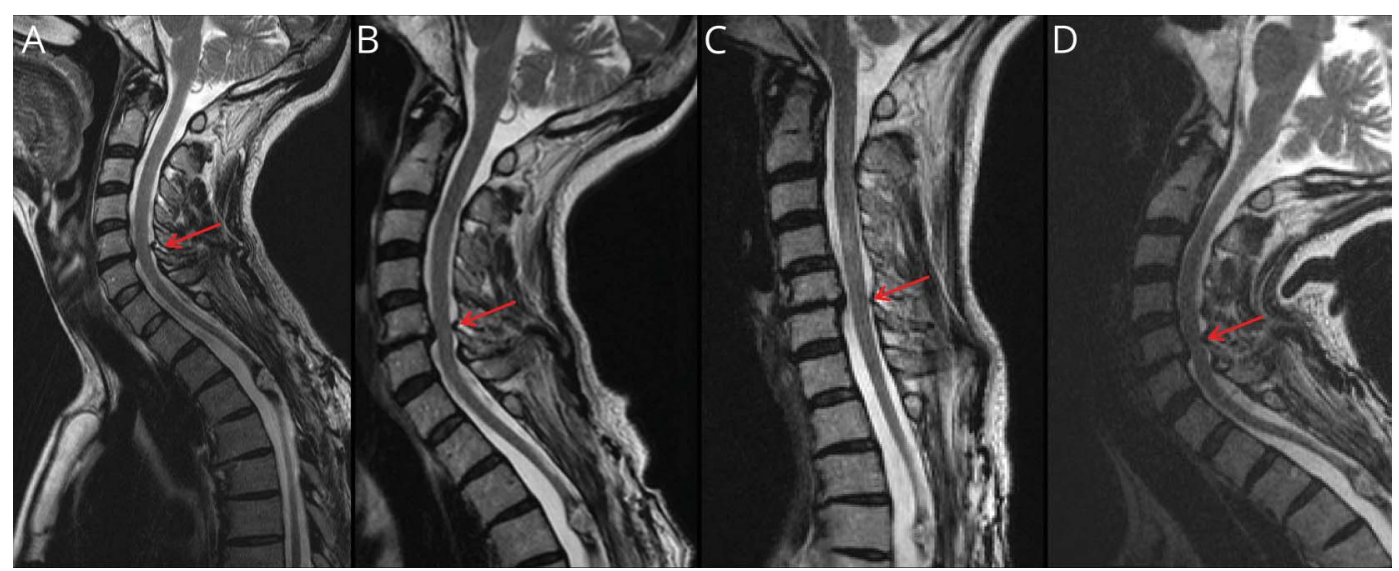

June 2000, sagittal T2* MRI with the neck in neutral position (A); August 2018, sagittal T2* MRI with the neck in neutral position (B), flexion (C), and extension (D).

\section{GO TO SECTION 4}




\section{Section 4}

Surgery was recommended to decompress the C5-C6 level and stabilize the segment. An anterior cervical discectomy and fusion would be the best option. However, an anterior approach was not ideal in the patient's case because of the risk of worsening her dysphagia from manipulation of the esophagus and distal nerves involved with swallowing mechanism. A C4-C6 posterior cervical laminectomy and fusion was performed with the fixation extended to $\mathrm{C} 4$ due to her osteoporosis. After a short period of inpatient physical rehabilitation, she experienced marked improvement of spasticity, strength, and paresthesias with improved gait.

\section{Discussion}

Patients with $\mathrm{CMs}$ of the spine can present with acute changes, progressive deterioration, or a stepwise neurologic worsening, which can mimic demyelinating disease. In the case described, the lack of new hemorrhage or further extension of the hemosiderin stain related to the thoracic spinal cord lesion, along with the new symptoms in the upper extremities, ruled out the thoracic $\mathrm{CM}$ as the sole reason for worsening.

Patients who have undergone surgery for an intramedullary lesion, especially a hemorrhagic CM, are at risk of developing tethering of the spinal cord from adhesions related to scarring between the spinal cord surface and the dura/ arachnoid mater. While imaging findings of spinal cord tethering are not that uncommon, few patients become symptomatic. Symptoms can develop acutely in the presence of a triggering event, which causes sudden stretching of the spinal cord with resultant damage as the cord is fixed by the tether rather than floating in the CSF. Some patients with tethering can experience a slow but progressive myelopathy because of repeated microtrauma from normal activities. However, symptomatic tethering manifesting more than 30 years after original surgery without inciting event would be unusual. In such cases, however, symptoms start after a relatively short interval following the original surgery as the tether develops and are not delayed in absence of an inciting event. ${ }^{1}$

The possibility of a new primary neurologic condition unrelated to the $\mathrm{CM}$ and previous surgery was also considered. This diagnostic possibility was raised because of the long interval from the last clinical event, without documented new hemorrhage and new onset of dysphagia, and loss of fine motor skills and atrophy in the hands. However, comprehensive EMG of the upper and lower extremities and laboratory tests did not show any evidence of neuropathy, myopathy, disorder of the neuromuscular junction, or other cause for myelopathy.
A myelopathy secondary to mechanical compression was at first considered unlikely because of the lack of important compression on the static spine imaging. ${ }^{2}$ However, a closer look of the cervical spine flexion/extension dynamic X-ray imaging suggested worsening of the retrolisthesis at C5-C6 with extension. A dynamic MRI was then obtained. When it was compared to a prior MRI (figure, A), the most recent study showed no change of the $\mathrm{CM}$ at $\mathrm{T} 3$, but interval progression of the retrolisthesis at C5-C6 in neutral position, although not dramatic (figure, B). Flexion MRI demonstrated mild reduction of the retrolisthesis and canal narrowing at C5-C6 (figure, C). Neck extension resulted in significant worsening of both retrolisthesis and spinal canal narrowing at C5-C6 (figure, D). This observation led us to the hypothesis that the patient's symptomatology could be caused by dynamic compression with repetitive microtraumas of the cord aggravated by the thoracic tethering. This suggested a dynamic compression in a patient with a tethered cord and decreased functional reserve as the main reason for her deterioration. The fact that her cord was fixed at the level of the prior laminectomy from tethering worsened the effects of repeated microtrauma from the dynamic compression at C5-C6. This hypothesis was confirmed by the postoperative functional recovery.

\section{Study funding}

No targeted funding reported.

\section{Disclosure}

The authors report no disclosures relevant to the manuscript. Go to Neurology.org/N for full disclosures.

\begin{tabular}{|c|c|c|c|}
\hline Name & Location & Role & Contribution \\
\hline $\begin{array}{l}\text { Elisa } \\
\text { Colombo, } \\
\text { MD }\end{array}$ & $\begin{array}{l}\text { Mayo Clinic, } \\
\text { Rochester, } \\
\text { MN }\end{array}$ & Author & $\begin{array}{l}\text { Drafted the manuscript for } \\
\text { intellectual content }\end{array}$ \\
\hline $\begin{array}{l}\text { Robert J. } \\
\text { Brown Jr, MD }\end{array}$ & $\begin{array}{l}\text { Mayo Clinic, } \\
\text { Rochester, } \\
\text { MN }\end{array}$ & Author & $\begin{array}{l}\text { Revised the manuscript for } \\
\text { intellectual content }\end{array}$ \\
\hline $\begin{array}{l}\text { Giuseppe } \\
\text { Lanzino, MD }\end{array}$ & $\begin{array}{l}\text { Mayo Clinic, } \\
\text { Rochester, } \\
\text { MN }\end{array}$ & Author & $\begin{array}{l}\text { Revised the manuscript for } \\
\text { intellectual content }\end{array}$ \\
\hline $\begin{array}{l}\text { Benjamin D. } \\
\text { Elder, MD, } \\
\text { PhD }\end{array}$ & $\begin{array}{l}\text { Mayo Clinic, } \\
\text { Rochester, } \\
\text { MN }\end{array}$ & Author & $\begin{array}{l}\text { Interpreted data, revised the } \\
\text { manuscript for intellectual } \\
\text { content }\end{array}$ \\
\hline
\end{tabular}

\section{References}

1. Mitha AP, Turner JD, Abla AA, Vishteh AG, Spetzler RF. Outcomes following resection of intramedullary spinal cord cavernous malformations: a 25-year experience. J Neurosurg Spine 2011;14:605-611.

2. Cao JM, Zhang JT, Yang DL, Yang YP, Xia HH, Yang L. Imaging factors that distinguish between patients with asymptomatic and symptomatic cervical spondylotic myelopathy with mild to moderate cervical spinal cord compression. Med Sci Monit 2017;23:4901-4908. 


\section{Neurology}

\section{Clinical Reasoning: 63-Year-old woman with thoracic cavernous malformation and delayed worsening myelopathy}

Elisa Colombo, Giuseppe Lanzino, Robert D. Brown, Jr, et al. Neurology 2019;93;1075-1078

DOI 10.1212/WNL.0000000000008635

This information is current as of December 9, 2019

\section{Updated Information \&} Services

References

Subspecialty Collections

\section{Permissions \& Licensing}

Reprints including high resolution figures, can be found at: http://n.neurology.org/content/93/24/1075.full

This article cites 2 articles, 0 of which you can access for free at: http://n.neurology.org/content/93/24/1075.full\#ref-list-1

This article, along with others on similar topics, appears in the following collection(s):

All Clinical Neurology

http://n.neurology.org/cgi/collection/all_clinical_neurology

All Spinal Cord

http://n.neurology.org/cgi/collection/all_spinal_cord

Disc disease

http://n.neurology.org/cgi/collection/disc_disease

MRI

http://n.neurology.org/cgi/collection/mri

Prognosis

http://n.neurology.org/cgi/collection/prognosis

Information about reproducing this article in parts (figures,tables) or in its entirety can be found online at:

http://www.neurology.org/about/about_the_journal\#permissions

Information about ordering reprints can be found online:

http://n.neurology.org/subscribers/advertise

Neurology ${ }^{\circledR}$ is the official journal of the American Academy of Neurology. Published continuously since 1951, it is now a weekly with 48 issues per year. Copyright @ 2019 American Academy of Neurology. All rights reserved. Print ISSN: 0028-3878. Online ISSN: 1526-632X.

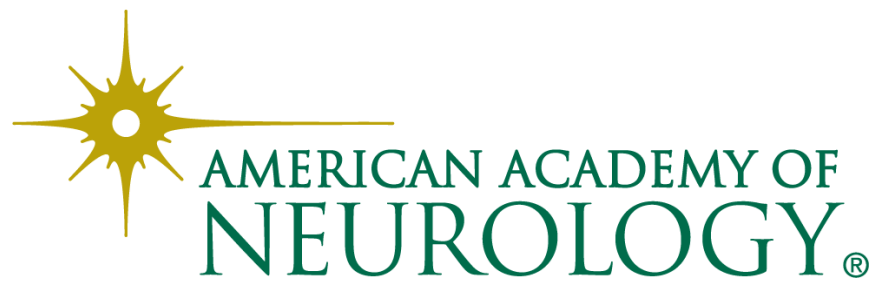

